\title{
ANALISA DAN PENERAPAN METODE SINGLE EXPONENTIAN SMOOTHING DAN MULTI AGENT SISTEM PADA PREDIKSI PENJUALAN
}

\author{
${ }^{1}$ Bekti Maryuni Susanto, ${ }^{2}$ Ery Setiyawan Jullev Atmadji \\ Progam Studi Teknik Komputer Jurusan Teknologi Informasi Politeknik Negeri Jember \\ Jln Mastrip Kotak Pos 164 Jember \\ 1bektipolije@gmail.com \\ ${ }^{2}$ setiyawanjullev@gmail.com
}

\begin{abstract}
Abstrak
Pada dunia bisnis stok barang merupakan sebuah hal yang sulit untuk diprediksi. Banyak hal yang menjadi penentu factor jumlah stocking barang. Salah satu factor utama adalah jumlah pesanan dan kondisi ekonomi.

Isu menarik dari proses peramalan kebutuhan barang adalah mendelegasikan tugas tersebut kepada asisten pribadi berupa perangkat lunak komputer. Kegiatan pengerajin untuck melakukan stocking barang akan sangat terbantu oleh perangkat lunak ini. Pendekatan perangkat lunak berbasis kecerdasan agen (intelligent agent) memungkinkan untuk membantu pengerajin dalam menentukan kemungkinan stok barang pada bulan selanjutnya.

Perangkat lunak berbasis intelligent agent ini dirancang menggunakan metodologi Prometheus, dan dikembangkan melalui platform JADE dengan menggunakan bahasa pemrograman Java. Pengembangan model berfokus pada bagaimana agen dapat membantu dalam melakukan peramalan terhadap kebutuhan stocking barang yang kemungkinan akan dipesan. Konsep yang diterapkan pada agen berdasarkan metodesingle exponential smoothing, dengan menggunakan histori barang selama 2 tahun terakhir.

Evaluasi dilakukan terhadap 24data histori data permintaan selama 2 tahun. Metode perbaikan data dengan menggunakan MSE dengan hasil paling optimal antara nilai alpha 0.3 hingga 0.6.
\end{abstract}

Kata Kunci-Multi Agent,MSE,Prometheus, Single Exponential Smoothing, Stocking.

In the business world stock of goods is a difficult thing to predict. Many things can be the deciding factor of the number of stocking goods. One major factor is the number of orders and economic conditions. Interesting issues from the process of forecasting the needs of the goods is delegate that task to a personal assistant in the form of computer software. Activities of craftsmen untuck do stocking goods will be greatly assisted by this software. Intelligence-based approach to software agents (intelligent agents) allows to help craftsmen in determining the likelihood of the stock of goods in the coming months.

Intelligent agent-based software is designed using methodology Prometheus, and developed through the JADE platform using the Java programming language. Development of a model focused on how agencies can help in forecasting the need for stocking goods that are likely to be booked. The concept is applied to the agent based on single exponential smoothing method, using history items during the last 2 years.

An evaluation of the historical data 24 demand data for 2 years. Repair methods MSE data using the most optimal results between the alpha value 0.3 to 0.6 .

Keywords-Multi Agent,MSE,Prometheus, Single Exponential Smoothing, Stocking.

\section{PENDAHULUAN}

Pada dunia bisnis pengambilan keputusan tentang strategi penjualan sangatlah diperlukan untuk mendapatkan keuntungan yang maksimal. Fluktuasi permintaan pelanggan yang terjadi di setiap distributor menyebabkan ketidakpastian dalam pengendalian produk dan proses produksi bagi perusahaan manufaktur yang berimbas juga pada masalah pemesanan material ke pemasok (Pakaja,2014). Keputusan penentuan jumlah produksi yang kurang tepat dapat menyebabkan kerugian baik bagi perusahaan manufaktur yang bersangkutan, pemasok maupun distributor (Zheng, 2011). Salah satu cara yang dapat dilakukan adalah 
dengan melakukan prediksi atau peramalan terhadap jumlah penjualan. peramalan merupakan perhitungan yang objektif dan dengan menggunakan data-data masa lalu, untuk menentukan sesuatu dimasa yang akan dating. (Sumayang, 2003 : 24)

Penelitian mengenai perancangan sistem informasi untuk mengintegrasikan sistem perusahaandalam supply chain telah banyak mendapat perhatian dalam literatur. Ali (2004) mengembangkansistem monitoring stok dan penjualan secara simultan dan real time berbasis mobile agent pada suplly chain. Elram dalam Chen (2004) menjelaskan perlunya sharing data dan informasi antara perusahaan manufaktur, pemasok dan distributor untuk pengendalian stok dalam supply chain. Verwijmeren (1999) menegaskan secara ekspisit tentang pentingnya teknologi informasi dalam pengendalian stok produk pada distributor yang terdistribusi. Westwood (1999) mengembangkan model pengendalian stok pada beberapa distributor dengan melakukan pemindahan stok di antara distributor. Zhou, et. al. (2000) memperhatikan model kerja sama antara perusahaan dengan perusahaan rekanan dan pemasoknya untuk menentukan pemilihan rekanan dalam menangani suatu kontrak. Hisyam dan Samadhi (2001) menambahkan sistem pendukung keputusan untuk merespon pesanan dari pelanggan yang berfluktuasi pada extended enterprise berbasis web. K.F. Au \& Ho (2002) mengimplementasikan model transaksi elektronik antar perusahaan pakaian di Hongkong yang tergabung dalam supply chain..

Untuk lebih memaksimalkan kinerja dari sistem peramalan, maka akan dikombinasikan dengan sebuah sistem agent cerdas yang bersifat autonomous berdasarkan lingkungan kerja dari agent, hal ini dikarenakan sebuah agent memiliki sifat yang disebut adaptive (Xiang et. al., 2009).

Istilah Agent sendiri mulai banyak dikenal di berbagai bidang, baik dalam bidang informatika dan ilmu komputer, seperti software engineering, artificial intelligence (AI), distributed sistem, dan sebagainya. Selain itu Agent juga dikenal dalam bidang lain yang terkait, misalnya bidang industri, manufacturing, bisnis, e-commerce, dan sebagainya. Hal ini menunjukkan bahwa teknologi Agent mulai banyak digunakan pada berbagai bidang ilmu tersebut. Namun demikian, definisi Agent sendiri masih kabur, karena setiap peneliti berusaha untuk mendefinisikan Agent sesuai dengan latar belakang ilmu yang mereka miliki. Akibatnya muncul penggunaan Agent dengan banner yang bermacammacam, misalnya penggunaan kata-kata, intelligent Agent, Agent technology, software Agent, autonomous Agent, ataupun Agent sendiri.

CV Dua Saudara adalah salah satu industry rumahan (Home Industry) yang bergerak di bidang permebelan. Selama ini dalam dalam melakukan stocking dan pembuatan mebel masih berdasarkan pesanan dan perkiraan. Barang akan dibuat berdasarkan pesanan atau momen-momen tertentu semisal menjelang idul fitri atau menjelang natal, karena pada saat-saat itu penjualan sangat tinggi. Proses pembuatan furniture ini memakan waktu minimal satu minggu, apabila ada pesanan yang akan dipakai secara mendadak maka produsen ini tidak mampu melayani pesanan tersebut. Tidak adanya program computer atau sejenisnya yang membantu dalam hal pencatatan ataupun inventaris pesanan membuat proses stock barang menjadi lebih susah.

Berdasarkan permasalahan di atas perlu dibangun sebuah aplikasi yang mampu melakukan peramalan terhadap permintaan serta pencatatan penjualan. Sistem yang dibangun ditujukan untuk menyelesaikan permasalahan di atas. Aplikasi peramalan dan pencatatan penjualan yang dibangun memanfaatkan kolaborasi Multi Agent Sistem dan Prediksi (forecasting). Kolaborasi antara Multi Agent Sistem dan Prediksi ini dipilih karena sistem ini memungkinkan untuk agent melakuakan proses peramalan sendiri berdasarkan lingkungan di miliki oleh agent tersebut, sehingga akan lebih memudahkan bagi pengguna dalam melakukan proses peramalan, serta aplikasi ini akan berguna pula sebagai pencatatan penjualan.

\section{TINJAUAN PUSTAKA}

A. Multi-Agent dengan menggunakan platform

JADE (Java Agent Development Framework) merupakan sebuah framework untuk mengembangkan perangkat lunak berbasis sistem multi-agent dan aplikasi intelligent agent yang sesuai dengan standar FIPA. JADE merupakan suatu kerangka kerja (framework) pengembangan perangkat lunak untuk mengembangkan sistem multi-agent seperti dinyatakan dalam (Bellifemine dkk, 2007). Platform JADE terbentuk dari berbagai container yang terdapat pada satu komputer, atau mungkin tersebar pada jaringan komputer. Container inilah yang menjadi tempat hidup bagi agenagen. Container menyediakan JADE run-time dan semua layanan-layanan yang dibutuhkan untuk penempatan dan pengeksekusian agen.

JADE menyediakan layanan platform yang disebut AMS (Agent Mobility Service) sehingga dapat mengimplementasikan mobilitas intraplatform. Hal ini memberikan kemampuan agen untuk berpindah dari sebuah container ike icontainer lain dalam platform yang sama. Oleh karena itu, JADE mendukung pengembangan sistem yang membutuhkan mobile agent.

Sebuah agen dapat memiliki tugas yang spesifik yang disebut dengan behavior. Sebuah behavior akan mempresentasikan tugas yang akan dikerjakan sebuah agen. Sebuah agen dapat memiliki lebih dari 
satu behavior dan agen dapat menjalankan lebih dari satu behavior disaat yang bersamaan, berikut deskripsinya:

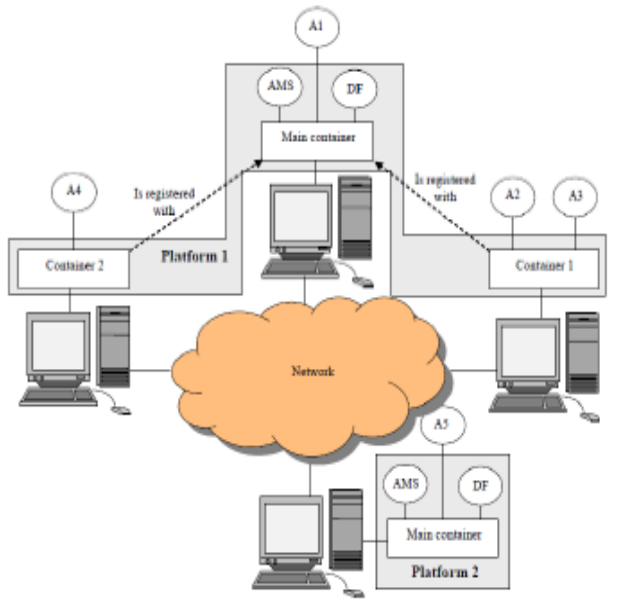

Gambar 1 Arsitektur JADE (Chaire,2009)

\section{B. Single Exponential Smoothing}

Pola data yang tidak stabil atau perubahannya besar dan bergejolak umumnyamenggunakan model pemulusan eksponensial (Exponential Smoothing Models). Metode SingleExponential Smoothing lebih cocok digunakan untuk meramalkan hal-hal yang fluktuasinya secaraacak(tidak teratur).

Menurut Pakaja (2012) Pemulusan Eksponensial merupakan metode peramalan rata-ratabergerak dengan pembobotan yang canggih, tetapi masih mudah digunakan. Metode inimenggunakan pencatatan data masa lalu yang sangat sedikit. Model ini mengasumsikan data berfluktuasi di sekitar nilai rata-rata yang tetap, tanpa mengikuti pola atau tren.Rumus Pemulusan Ekponensial Tunggal:

$$
\hat{\mathrm{Y}}_{\mathrm{t}+1}=\alpha \mathrm{Y}_{\mathrm{t}}-(1-\alpha) \hat{\mathrm{Y}}_{\mathrm{t}}
$$

Keterangan:

$\hat{\mathrm{Y}}_{\boldsymbol{t}+\mathbf{1}}=$ nilai ramalan untuk periode berikutnya.

$\alpha \quad=$ konstantapemulusan.

Yt = data baru atau nilai Y yg sebenarnya

padaperiode $\mathrm{t}$.

$\hat{\mathrm{Y}}_{\boldsymbol{t}} \quad=$ nilai pemulusan yang lama atau rata-rata pemulusan hingga periode $\mathrm{t}-1$

\section{III.TUJUAN DAN MANFAAT PENELITIAN}

Tujuan dari penelitian ini adalah untuk mendapatkan nilai peramalan yang lebih optimal dengan memanfaatkan agent sebagai salah satu mekanisme otomatisasi terhadap data yang telah tersedia.

Penelitian ini juga mempunyai manfaat sebagai salah satu nilai dalam melakukan optimalisasi peramalan terhadap barang dengan memanfaatkan agent.

\section{IV.METODE PENELITIAN}

Tahapan yang akan dilakukan dalam penelitian ini meliputi karakteristik Single Exponential Smoothing, desain Multi-agent untuk peramalan kebutuhan barang dengan bahasa pemrograman java dan framework jade.

\section{A. Analisis Sistem Usulan}

Berdasarkan penjelasan di atas maka untuk mengatasi permasalahan tersebut peneliti mengusulkan sebuah sistem berbasis komputer kepada pengusahayang akan melakukan peramalan terhadap permintaan. Sistem agent cerdas merupakan salah satu system autonomous yang bisa berkerja tanpa adanya supervise dari user, pemodelan dan pemanipulasian data. Sistem itu digunakan untuk membantu pengerajin dalam melakukan stocking barang, data histori dari pembelian akan dijadikan acuan utama dalam melakukan peramalan, sedangkan agent akan bertindak sesuai dengan lingkungan yang diciptakan oleh user itu sendiri [5]. Sistem ini bekerja secara waktu nyata (real time) yaitu bahwa sistem akan memonitor aktifitas dari permintaan pengunjung dan melakukan perkiraan untuk pesanan selanjutnya kepada pemilik melalui mekanisme pengiriman pesan. Data Hasil pengamatan terhadap aktifitas pemesanan tersebut akan dijadikan sebagai acuan sehingga apabila ada aktifitas baru yang masuk maka agent akan secara otomatis dilakukan pencatatan kedalam basis data. Sistem usulan ini diharapkan dapat membantu pengerajin dalam melakukan stocking barang. Secara garis besar mekanisme sistem multi agent seperti terlihat dibawah ini.

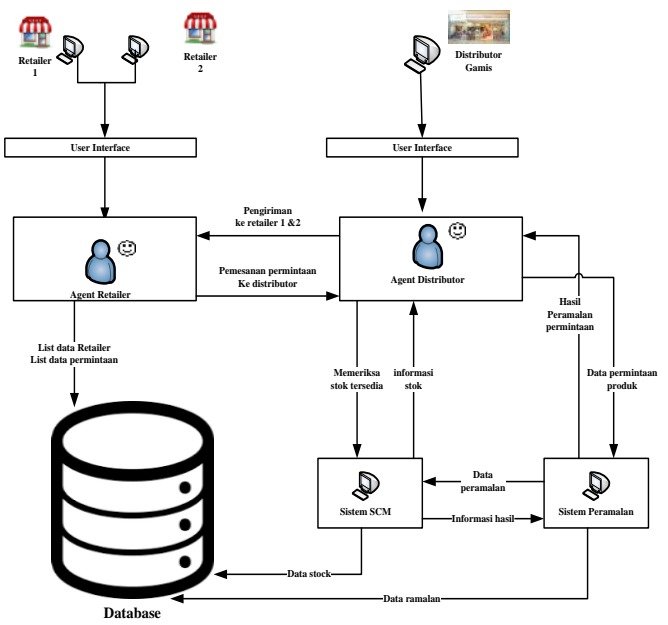

\section{Gambar 2Perancangan Garis Besar Sistem}

Oleh karena sistem usulan (autonomous smart agent) digunakan untuk mengatasi persoalan bagaimana melakukan peramalan kebutuhan stok barang.Istilah Agent mulai banyak dikenal di berbagai bidang, baik dalam bidang informatika dan 
ilmu komputer, seperti software engineering, artificial intelligence (AI), distributed system, dan sebagainya.

Sedangkan mekanisme usulan untuk training dan testing data ditunjukkan pada gambar berikut :

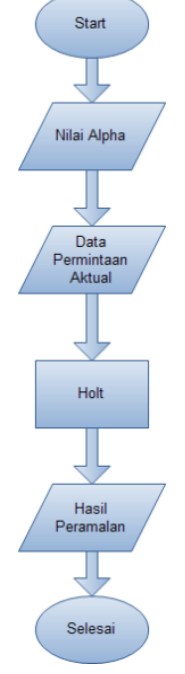

\section{Gambar 3 Flow Proses Peramalan}

\section{HASIL DAN LUARAN YANG DIHARAPKAN}

Hasil dan pembahasan berisi penjelasan mengenai hasil analisis terhadap sistem berjalan, analisis sistem usulan serta keluaran dari penelitian.

\section{B. Analisis Sistem}

Peramalan terhadap kebutuhan barang merupakan salah satu masalah yang pelik, pengerajin harus jeli memprediksi kebutuhan dan pangsa pasar dari sebuah produk sehingga tidak merugi, hal tersebut dapat dibantu dengan menggunakan prediksi dengan dibantu oleh computer.

Dari hasil wawancara yang telah dilakukan, selama ini pemesanan barang dilakukan secara manual berdasarkan pesanan dari pemberli dan sangat jarang melakukan stocking barang, hal ini menyebabkan ketika ada pesanan yang datang secara mendadak pengerajin membutuhkan waktu untuk membuat barang tersebut.

Berdasarkan kondisi di atas maka dibutuhkan sebuah mekanisme yang dapat membantu pengerajin dalam proses peramalan kebutuhan, khususnya dalam hal stocking barang dengan mengetahui terlebih dahulu histori pesanan, sehingga akan didapatkan hasil peramalan yang lebih optimal.

\section{Hasil Peramalan}

Hasil penelitian yang diperoleh dapat diuraikan berdasarkan pencapaian tujuan utama sistem agen yaitu pembentukan model peramalan melalui proses pembelajaran dan proses validasi berdasarkan metode Single Exponential Smoothing. Berdasarkan pencapaian ini, selanjutnya dilakukan percobaan pada aplikasi untuk melakukan proses peramalan kebutuhan bahan dan penjualan hasil produksi. Proses ini diakomodasi oleh AgentPeramalan dengan melihathistory perkerjaan,banyaknya penjualan dan menjalin komunikasi dengan agen-agen yangterkait dengan proses penjualan pada peramalan tersebut. Agen tersebut adalahAgenPemilik. Pengujian terakhir AgentPemilik akan memberikan data baru yang akan dijadikan parameter untuk meramalkan berapa banyak data yang harus diberi dengan consensus peramalan.Dalam penelitian ini, koleksi data yang digunakan berupa hasil penjualan barangsebanyak dua tahun. Data-data tersebutdigunakan dalam proses pre-processing, proses pembelajaran, dan proses peramalan. Dalam percobaan aplikasi ini digunakan 20 data permintaan baru untuk ditentukan berapa banyak yang harus disediakan oleh pengguna dalam hal ini pengerajin, dengan detail data sebagai berikut

Tabel 1 Detail Permintaan

\begin{tabular}{|c|c|c|}
\hline Bulan & Periode & $\begin{array}{c}\text { Permintaan Pasuran } \\
(\mathrm{Xi})\end{array}$ \\
\hline Januari 2013 & 1 & 3 \\
\hline $\begin{array}{c}\text { Februari } \\
\text { 2013 }\end{array}$ & 2 & 4 \\
\hline Maret 2013 & 3 & 5 \\
\hline APRIL 2013 & 4 & 3 \\
\hline Mei 2013 & 5 & 5 \\
\hline Juni 2013 & 6 & 6 \\
\hline Juli 2013 & 7 & 4 \\
\hline $\begin{array}{c}\text { Agustus } \\
\text { 2013 }\end{array}$ & 8 & 6 \\
\hline Sep-13 & 9 & 7 \\
\hline $\begin{array}{c}\text { Oktober } \\
2013\end{array}$ & 10 & 6 \\
\hline Nov-13 & 11 & 4 \\
\hline $\begin{array}{c}\text { Desember } \\
2013\end{array}$ & 12 & 6 \\
\hline Januari 2014 & 13 & 6 \\
\hline $\begin{array}{c}\text { Februari } \\
2014\end{array}$ & 14 & 6 \\
\hline
\end{tabular}

Setelah didapatkan data tersebut maka proses selanjutnya adalah menyimpan data tersebut yang kemudian akan dilakukan proses training oleh agentPeramalan melalui mekanisme pengiriman pesan oleh agentDistributor dengan menggunakan 
mekanisme FIPA seperti gambar dibawah ini :

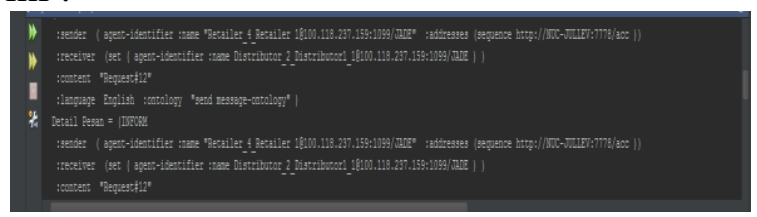

Gambar 4 Pesan dari Agent

Setelah menerima pesan dari agentRetailer, selanjutnya agent distributor akan meneruskan pesan tersebut kepada agent peramlana, yang selanjutnya berdasrkan pesan tersebut akan dilakukan proses peramalan dengan detail pesan seperti dibawah ini

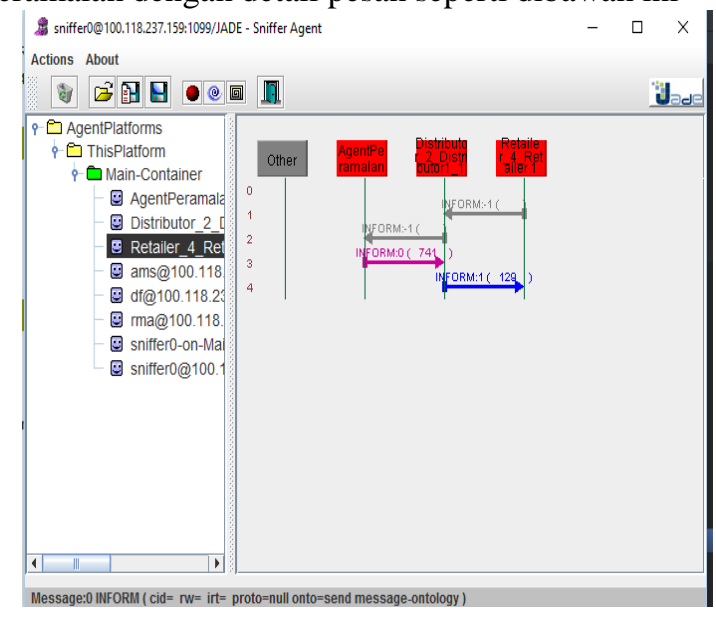

Gambar 5 Detail pengiriman pesna antar agent

Setelah dilakukan peramalan oleh agentPeramalan maka selanjutnya agentperamalan akan memberikan hasilnya kepada agent distributor, yang selanjutnya akan memberikan informasi kepada pengerajin tentang jumlah yang harus distok pada bulan berikutnya seperti pada gambar dibawah ini

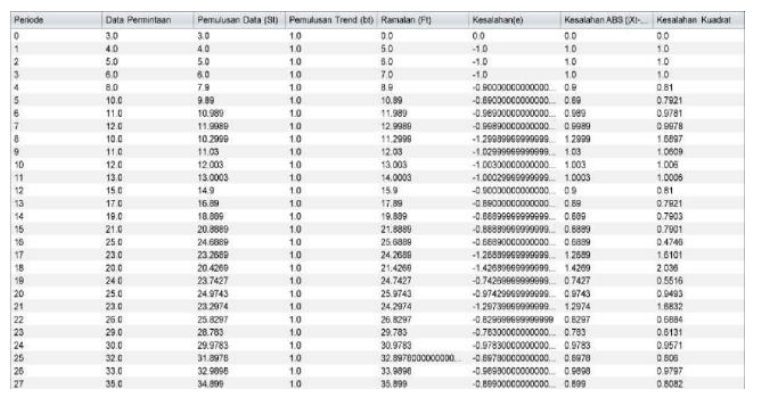

Gambar 6 Hasil peramalan

Pengambilan data perkiraan jumlah barang yang distok dalam penelitian ini menggunakan pendekatan MSE sehingga nilai MSE yang paling kecil akan dipakai dalam proses selanjutnya, perbandingan nilai MSE ini akan dipakai untuk dijadikan acuan serta perbandingan antara permintaan hasil peramalan dan permintaan sesungguhnya, hal ini ditunjukkan dengan graphic

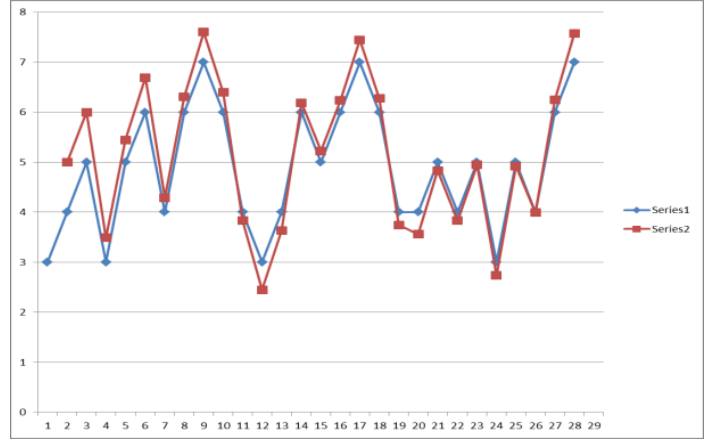

Gambar 7 Perbandingan antara data asli dengan hasil peramalan

Berdasarkan kemampuan dan karakteristik ini, agen mampu melakukan proses peramalan data permintaan sehingga aplikasi manajemen rantai pasokan yang sudah ada dapat diberikan kecerdasan tambahan melalui aplikasi ini. Namun, dalam proses rantai pasokan tidaklah cukup dalam penentuan stok barang hanya melalui history permintaan, karena pada kenyataannya masih banyak faktor non teknis yang menjadi acuan dalam penentuan jumlah stok barang, oleh karena itu pada sistem ini admin masih berperan penting dalam penentuan jumlah stok barang. Berdasarkan karakteristik yang dimiliki oleh agen, tentunya dapat dipikirkan untuk menambah atau membuat agen baru yang akan memberikan solusi terhadap permasalahan tentang peramalan terhadap stok barang.

\section{VI.KESIMPULAN}

Berdasarkan pembahasan tentang penerapan multiagen sistem untukpermalan dengan menggunakan algoritma Single Exponential Smothing, makabeberapa kesimpulan yang diperoleh, antara lain:

1. Hasil yang diperoleh akan membantu pemilik untuk mengetahui stok yang harus tersedia bulan selanjutnya yang telah dipelajari dari sebaran data oleh system agent.

2. Tiga agen yang diimplementasikan, yaitu AgentPeramalan, AgentDistributor dan AgentRetailer sudah mampu melakukan komunikasi yangmenghasilkan nilai hasil peramalan dengan fungsinya masing masing sehingga tiga agen merupakan batas minimal dari sebuah multiagen sistem untuk melakukan peramalan terhadap permintaan penjualan.

3. Hasil yang diperoleh pada tahap pembelajaran akan diperbaiki melaluitahap validasi sehingga dapat menghasilkan permalan yang lebihbaik serta dapat mengenali outliers.

4. Sensitivitas dari pengenalan outlier sangat tinggi, sehingga nilai dari MSE sangat fluktuatif antara satu alpha dengan alpha yang lain hal 
5.

didasari oleh kesenjangan permintaan antara bulan pertama dan bulan kedua.

6. Hasil pengujian terhadap 24 data penjualan terhadap beberapa nilaialpha menunjukkan bahwa besaran nilai alpha sangat berpengaruh terhadap hasil peramalan, dalam hal in didapatkan nilai alpha sebesar 0.6

\section{DAFTAR PUSTAKA}

Ali, M., (2004),. "Perancangan Infra Struktur Sistem Informasi Untuk Pengendalian Stok dan Penjualan Secara Simultan dan Real Time Berbasis Mobile Agent pada Supply Chain", Tesis S2 Teknik dan Manajemen Industri, ITB, Bandung

$\mathrm{Au}, \quad$ K.F., Ho, D.C.K., (2002), "Electronic Commerce and Supply Chain Management Value Adding service for Clothing Manufacturing”, Emerald Integrated Manufacturing Sistems

Bellifemine, F., Caire, G. and Greenwood, D., (2007), Developing Multi-Agent Sistems with JADE,

Chen, I. J., Paulraj, A., (2004), “Towards a theory of supply chain management : the constructs and measurements", Journal of Operations Managemen 22 (2004) 119 - 150

Hisyam, M, Samadhi, A., (2001), "Perancangan Sistem Pendukung Keputusan untuk Order Respon pada Extended Enterprise“, Prosiding Seminar Nasional Sistem Produksi V, Bandung

Hu, N., Liu, L. and Zhang, J., 2007, Analyst Forecast Revision and Market Sales Discovery of Online Word of Mouth. 2007 40th Annual Hawaii International Conference on Sistem Sciences (HICSS'07), p.210c-210c.

Lund, A. M. (2001). Measuring usability with the USE questionnaire. Usability Interface 8(2), 3 6.

Margi,K., Pendawa,S (2015). Analisa Dan Penerapan Metode Single Exponential Smoothing Untuk Prediksi Penjualan Pada Periode Tertentu (Studi Kasus : Pt. Media Cemara Kreasi),Prosiding SNATIF Vol.2, 2015

Pakaja, F., Naba, A., Purwanto. (2012), Peramalan Penjualan Mobil Menggunakan Jaringan Syaraf Tiruan dan Certainty Factor, Jurnal EECCIS, Vol.6, No.1, Juni 2012.

Singh, Y. K. (2006). Fundamental of Research Methodology and Statictic. New Delhi: New Age International (P) Ltd.

Verwijmeren, M.A.A.P., (1998), "Networked Inventory Management by Distributed Object Technology" Koninklijke KPN NV, KPN Research, Leidschendam, The Netherlands.
Wahono, R.S., 2001, Pengantar Software Agent: Teori dan Aplikasi Romi. Proceedings of the IECI Japan Workshop 2001, 3(1), pp.3-21.

Westwood, J.B., (1999), "Retail inventory movement - a case study in rasionalisation" International Journal of Physical Distribution and Logistica Management, Vol 29 No. 7/8, pp. 444-452, MCB University Press.

Wooldridge, M., 2002, An Introduction to Multiagent Sistems, 2nd edition, John Wiley dan Sons Ltd, Great Britain.

Zheng; Zhong. 2011. Time series forecasting using a hybrid RBF neural network and AR model based on binomial smoothing. World Academy of Science, Engineering and Technology 75. 